\title{
PEMBELAJARAN KOOPERATIF TEAM GAMES TOURNAMENT DAN LEARNING CYCLE PADA MATA PELAJARAN ELEKTRONIKA DIGITAL
}

\author{
Ganti Depari \\ Jurusan Pendidikan Teknik Elektro FPTK UPI \\ Jl. Dr. Setiabudhi No.207 Bandung 40154 \\ gantidepari@yahoo.com
}

\begin{abstract}
Abstrak: Penelitian ini bertujuan untuk membandingkan efektivitas model pembelajaran kooperatif team games tournament dengan model pembelajaran learning cycle terhadap prestasi belajar siswa. Kedua pembelajaran merupakan menekankan dimana peserta didik bekerja dalam kelompok kecil untuk saling membantu satu sama lainnya dalam mempelajari materi pelajaran dengan berpusat pada siswa (student centered). Metode yang digunakan yaitu kuasi eksperimen dengan subyek terdiri dari dua kelas yaitu kelas X TAV 3 dan X TAV 4. Hasil penelitian menunjukkan bahwa terdapat perbedaan rata-rata hasil belajar antara model pembelajaran learning cycle $(0,58)$ dengan Team games tournament $(0,73)$ yaitu $t_{\text {hitung }}=3,69$ sehingga diperoleh $t_{\text {hitung }}=3,69>$ $\mathrm{t}_{\text {tabel(0,95)(58) }}=1,676$. Penelitian ini dapat disimpulkan bahwa pembelajaran dengan menggunakan model pembelajaran kooperatif team games tournament lebih baik dibandingkan dengan model learning cycle dalam meningkatkan prestasi belajar siswa.
\end{abstract}

Kata kunci: model pembelajaran, elektronika, digital

\begin{abstract}
This study discusses the comparison of the effectiveness of Team games tournament cooperative learning model and learning cycle model on students' achievement. Both of these methods emphasize a situation where students work in small groups and help each other to learn the course material. Students become the center of the learning activity (student-centered). This study uses quasi-experiment method, with subjects consisting of two classes, i.e. class X TAV 3 and X TAV 4. The results show that there is a difference in average academic achievement between learning cycle model $(0,58)$ and team games tournament $(0,73) . \mathrm{t}_{\mathrm{obt}}=3,69$, thus $\mathrm{t}_{\mathrm{obt}}=3,69$ $>\mathrm{t}_{\text {table(0.95)(58) }}=1,676$. It is concluded that a learning activity with TGT cooperative learning model is better than a learning activity with learning cycle model in improving students' achievement.
\end{abstract}

Keywords: learning models, electronics, digital

\section{PENDAHULUAN}

Guru memiliki peran vital dalam proses pembelajaran di kelas, guru memiliki tugas dan tanggung jawab menyusun rencana pembelajaran, melaksanakan kegiatan pembelajaran, mengevaluasi, menganalisis hasil evaluasi, dan melakukan tindak lanjut hasil pembelajaran. Guru akan menjadi "aktor" penentu keberhasilan siswa dalam mengadopsi dan menumbuhkembangkan nilai-nilai kehidupan. Tuntutan dalam dunia pendidikan sudah banyak berubah, guru perlu menyusun dan melaksanakan kegiatan belajar mengajar dimana anak dapat aktif membangun pengetahuannya sendiri. Sesuai dengan pandangan konstruktivisme yaitu keberhasilan belajar tidak hanya bergantung pada lingkungan atau kondisi belajar, tetapi juga pada pengetahuan awal siswa.

Berdasarkan hasil penelitian Irdam Mardiana (2007 : 81), diketahui bahwa prestasi belajar siswa dengan menggunakan model pembelajaran kooperatif tipe Team Games Tournament dengan rata-rata 72,83 lebih baik dibandingkan prestasi siswa dengan 
menggunakan model pembelajaran konvensional dan memiliki rata-rata 58,83. Pemilihan strategi, pendekatan, metode, teknik dan model pembelajaran yang menarik dan tepat dapat membantu guru dan peserta didik mencapai tujuan pembelajaran. Salah satu model pembelajaran dapat dikembangkan oleh guru yaitu pembelajaran kooperatif TGT dan model pembelajaran siklus belajar (learning cycle), dimana kedua model pembelajaran berpusat pada siswa (student centered). Tujuan dari penelitian ini yaitu mengetahui seberapa besar perbedaan antara penggunaan model pembelajaran siklus belajar (learning cycle) dan model pembelajaran TGT dengan membandingkan prestasi belajar siswa.

Pembelajaran kooperatif TGT merupakan hasil modifikasi pembelajaran tutorial dimana pada saat diskusi kelompok didesain kelompok kooperatif dan diberi istilah model diskusi "berpikir-berpasangan-berempat" atau think-pair-square, yaitu dikembangakan oleh Frank Lyman dan Spencer Kagan. TGT terdiri dari 5 langkah tahapan yaitu: tahap presentasi kelas (class precentation), belajar dalam kelompok (Team), permainan (games), pertandingan (tournament), dan perhargaan kelompok (team recognition). TGT yaitu salah satu tipe pembelajaran kooperatif yang menempatkan siswa dalam kelompok belajar yang beranggotakan 5 sampai 6 orang siswa yang memiliki kemampuan, jenis kelamin dan suku kata atau ras yang berbeda. Dengan adanya heterogenitas anggota kelompok, diharapkan dapat memotivasi siswa untuk saling membantu antar siswa yang berkemampuan lebih dengan siswa yang berkemampuan kurang dalam menguasai materi pelajaran. Guru menyajikan materi, dan siswa bekerja dalam kelompok mereka.

Kerja kelompok guru memberikan Lembar Kerja Siswa (LKS) kepada setiap kelompok. Tugas yang diberikan dikerjakan bersama-sama dengan anggota kelompoknya. Apabila ada dari anggota kelompok yang tidak mengerti dengan tugas yang diberikan, maka anggota kelompok yang lain bertanggungjawab untuk memberikan jawaban atau menjelaskannya, sebelum mengajukan pertanyaan tersebut kepada guru. Hal ini akan menyebabkan tumbuhnya rasa kesadaran pada diri siswa bahwa belajar secara kooperatif itu menyenangkan. Untuk memastikan bahwa seluruh anggota kelompok telah menguasai pelajaran, maka seluruh siswa akan diberikan permainan akademik. Dalam permainan akademik siswa akan dibagi dalam meja turnamen, dimana setiap meja turnamen terdiri dari 5 sampai 6 orang yang merupakan wakil dari kelompoknya masing-masing. Dalam setiap meja permainan diusahakan agar tidak ada peserta yang berasal dari kelompok yang sama. Siswa dikelompokkan dalam satu meja turnamen secara homogen dari segi kemampuan akademik, artinya dalam satu meja turnamen kemampuan setiap peserta diusahakan agar setara. Permainan ini diawali dengan memberitahukan aturan permainan. Setelah itu permainan dimulai dengan membagikan kartu soal untuk bermain (kartu soal dan kunci ditaruh terbalik 
di atas meja sehingga soal dan kunci tidak terbaca). Permainan pada tiap meja turnamen dilakukan dengan aturan sebagai berikut.

Pertama, setiap pemain dalam tiap meja menentukan dulu pembaca soal dan pemain yang pertama dengan cara undian. Kemudian pemain yang menang undian mengambil kartu undian yang berisi nomor soal dan diberikan kepada pembaca soal. Pembaca soal akan membacakan soal sesuai dengan nomor undian yang diambil oleh pemain. Selanjutnya soal dikerjakan secara mandiri oleh pemain dan penantang sesuai dengan waktu yang telah ditentukan dalam soal. Setelah waktu untuk mengerjakan soal selesai, maka pemain akan membacakan hasil pekerjaannya yang akan ditangapi oleh penantang searah jarum jam.

Skor yang diperoleh setiap peserta dalam permainan akademik dicatat pada lembar pencatat skor. Skor kelompok diperoleh dengan menjumlahkan skor-skor yang diperoleh anggota suatu kelompok. Kemudian dibagi banyaknya anggota kelompok tersebut. Skor kelompok ini digunakan untuk memberikan penghargaan tim berupa sertifikat dengan mencantumkan predikat tertentu ataupun penghargaan yang diberikan bisa dalam bentuk yang lain.

Menurut pandangan kontruktivisme, otak siswa pada dasarnya tidak seperti gelas kosong yang siap diisi dengan air, atau siap diisi dengan semua informasi yang berasal dari pikiran guru, melainkan otak siswa tidak kosong tetapi telah berisi pengetahuan yang dikonstruksi siswa sendiri sewaktu anak berinteraksi dengan lingkungan. Implikiasi dari pandangan ini adalah bahwa pengetahuan tidak dapat utuh ditransfer dari piokiran guru kepikiran siswa, tetapi siswalah yang harus aktif secara mental membangun pengetahuan dan pemahaman dalam proses pembelajaran.

Sampai saat ini masih ada sebagian guru yang menganut teori tabula rasa yaitu bahwa pengetahuan dapat dipindahkan secara utuh dari pikiran guru ke pikiran siswa. Hal ini telah telah menimbulkan berbagai kegagalan pendidikan umum khususnya pendidikan di sekolah kejuruan. Berbeda halnya dengan sebagian ilmuwan yang menganut paham kognitif, dan percaya kepada model konstuktivis tentang pengetahuan. Mereka berusaha untuk menjawab pertanyaan epistimologi mengenai belajar yaitu "bagaimana kita menjadi tahu tentang apa yang kita ketahui" jawaban yang diberi tahu pengamat konstuktivisme adalah menurut Bodnes (1986), bahwa "pengetahuan itu dibangun dalam pikiran siswa".

Teori konstruktivisme dianggap sebagai pandangan baru dalam pendidikan meskipun sebenarnya konstruktivisme menggunakan pandangan filsafat, pandangan ini dikemukakan Giambattista Vico (1710), “apa yang dipelajari akan bermakna bagi individu apabila bahan ajar yang dikaji dimulai dari apa yang telah diketahui peserta didik sebelumnya”. 
Piaget (1971), percaya bahwa "setiap makhluk hidup beradaptasi dan dan mengorganisasi lingkungan fisik di sekitarnya agar tetap hidup”. Bagi Piaget, pikiran dan tubuh juga terkena aturan main yang sama. Oleh karena itu, ia berpikir bahwa perkembangan pemikiran juga mirip dengan perkembangan biologis, yaitu perlu beradaptasi dan mengorganisasi dengan lingkungan sekitar. Piaget sendiri menyatakan bahwa teori pengetahuan itu pada dasarnya adalah teori adaptasi pikiran ke dalam suatu realitas, seperti organism beradaptasi dengan lingkungannya, berhasil meneliti secara ilmiah pandangan konstruktivisme dengan mengemukakan teori tentang struktur genetik. Dalam tesisnya Piaget mengemukakan bahwa organism menyusun pengalaman dengan jalan menciptakan struktur mental dan menerapkannya dalam pengalaman. Piaget mendeteksi eksistensi struktur tersebut berdasarkan studi terhadap individu. Berdasarkan studi tersebut diketahui adanya suatu proses aktif yang memungkinkan organism atau individu yang berinteraksi dalam lingkungan dan mentranformasikan lingkungan dalam pikirannya dengan bantuan struktur yang telah ada dalam pikirannya (Kueller, 1984). Informasi baru diterima siswa pada waktu ia berinteraksi dengan lingkungannya akan membentuk struktur kognitif tertentu. Menurutnya struktur pikiran merupakan sumber pemahaman manusia tentang dunia realita. Ia juga mengemukakan struktur kognitif interpretasi manusia berkembang, sebagai hasil dari interaksi yang lebih kompleks dengan dunia realita.

Pendekatan konstruktivisme dalam pembelajaran menekankan pentingnya peran pengetahuan awal dalam belajar. Dalam merancang aktivitas kelas, guru harus membuat program pengajarannya atas dasar pengetahuan siswa. Dalam kenyataannya, jika guru tidak mengetahui pengetahuan awal siswa, maka dapat terjadi miskonsepsi, jika terjadi miskonsepsi maka akan menimbulkan kesulitan belajar. Menurut pandangan konstruktivisme, kegiatan belajar adalah kegiatan yang aktif dimana peserta didik membangun sendiri pengetahuannya. Peserta didik mencari arti sendiri dari apa yang mereka pelajari. Ini merupakan proses yang menesuaikan konsep dari ide-ide baru dengan kerangka berpikir yang telah ada dalam pikiran mereka (Suparno 1997:62).

Menurut prinsip konstruktivisme, seorang seorang pengajar atau guru berperan sebagai mediator dan fasilitator yang membantu agar proses belajar siswa berjalan dengan baik. Oleh karena itu, tidak ada mutu strategi mengajar satu-satunya dapat digunakan dimanapun dan dalam situasi apapun. Setiap guru yang baik akan berusaha mengembangkan caranya sendiri dalam mengajar. Prinsip yang kembangkan dalam konstruktivisme yaitu:

1. Pengetahuan dibangun oleh siswa sendiri, baik secara personal maupun sosial.

2. Pengetahuan tidak dapat dipindahkan dari guru ke murid, kecuali hanya dengan kreativitas murid sendiri untuk menalar. 
3. Murid aktif mengkontruksi terus menerus, sehingga selalu terjadi perubahan konsep yang lebih rinci, lengkap, sesuai dengan konsep ilmiah.

4. Guru sekedar membantu menyediakan sarana dan situasi agar proses kontruksi siswa berjalan mulus.

Siklus belajar (learning cycle) merupakan suatu model pembelajaran dengan berpusat pada siswa (student centered). Strategi mengajar model siklus belajar memungkinkan seorang peserta didik untuk tidak hanya mengamati hubungan, tetapi juga menyimpulkan dan menguji penjelasan tentang konsep-konsep yang dipelajari. Karakteristik kegiatan belajar pada masing-masing tahap learning cycle mencerminkan pengalaman belajar dalam mengkontruksi dan mengembangkan pemahaman konsep. Model learning cycle dalam penelitian ini yaitu model yang sudah mengalami perkembangan dalam istilah fasenya.

Pada tahap eksplorasi, siswa diberi kesempatan untuk memanfaatkan panca inderanya semaksimal mungkin dalam berinteraksi dengan lingkungan. Kegiatan eksplorasi diharapkan timbul ketidakseimbangan dalam struktur mentalnya (cognitive disequilibrium) ditandai dengan munculnya pertanyaan dan mengarah pada berkembangnya daya nalar tingkat tinggi (high level reasoning), diawali dengan kata-kata seperti mengapa dan bagaimana. Munculnya pertanyaan-pertanyaan tersebut sekaligus merupakan indikator kesiapan siswa untuk menempuh fase berikutnya.

Pada fase pengenalan konsep diharapkan terjadi proses menuju kesetimbangan antara penguasaan konsep siswa dengan konsep baru dipelajari melalui kegiatan dengan membutuhkan daya nalar seperti menelaah sumber pustaka dan berdiskusi. Pada tahap pengenalan konsep siswa mengenal istilah berkaitan dengan konsep baru. Fase penerapan konsep dapat meningkatkan pemahaman konsep dan motivasi belajar, karena siswa mengetahui penerapan nyata dari konsep. Implementasi learning cycle dalam pembelajaran menempatkan guru sebagai fasilitator yakni mengelola berlangsungnya fase tersebut mulai dari perencanaan (terutama pengembangan perangkat pembelajaran), pelaksanaan (terutama pemberian pertanyaan arahan dan proses pembimbingan) sampai evaluasi. Efektifitas implementasi learning cycle biasanya diukur melalui observasi proses dan pemberian tes. Jika ternyata hasil dan kualitas pembelajaran tersebut ternyata belum memuaskan, maka dapat dilakukan siklus berikutnya dan pelaksanaannya harus lebih baik dibanding siklus sebelumnya dengan cara mengantisipasi kelemahan siklus sebelumnya, sampai hasilnya memuaskan.

Terdapat beberapa perbedaan pada model pembelajaran TGT dengan model pembelajaran siklus belajar (learning cycle). Model pembelajaran TGT menerapakan dimana siswa harus mengerjakan LKS atau mempelajari modul dan mempresentasikannya. Adanya 
turnamen akademik yang bersifat permainan dengan membagi kelompok secara heterogen. Adanya penghargaan kelompok dan pergeseran (bumping) setelah pelaksanaan turanamen akademik. Sedangkan model pembelajartan siklus melajar menekankan fase, yaitu: fase pengenalan konsep pengetahuan awal siswa lebih digali, tidak ada turnamen akademik, dan pembelajaran lebih bersifat diskusi dengan siswa sekelasnya ataupun dengan guru.

Elektronika digital adalah salah satu mata pelajaran yang mempunyai kompetensi standar. Menguasai elektronika digital meliputi: gerbang logika dasar, rangkaian kombinasi, rangkaian sekuensial dan dasar analog to digital converter maupun dasar digital to analog converter. Materi pokok pembelajaran elektronika digital antara lain: gerbang logika dasar seperti gerbang AND, gerbang OR, gerbang NOT; rangkaian kombinasi seperti gerbang NAND, gerbang NOR, gerbang EX-OR, gerbang EX-NOR, pembanding adder, substractor, decoder, encoder. Rangkaian sekuensial seperti: flip-flop dasar, SR flip-flop, JK flip-flop, T flip-flop, D flip-flop, counter, register. Selanjutnya pada penelitian yang digunakan materi elektronika digital yang meliputi Rangkaian Kombinasi seperti gerbang NAND, gerbang NOR, gerbang exclusive OR, gerbang exclusive NOR, half adder, full adder, substractor, decoder dan enkoder.

\section{METODE}

Metode yang digunakan dalam penelitian ini yaitu kuasi eksperimen. Prosedur penelitian menggunakan desain kelompok kontrol prates-postes tanpa acak (pretest-posttest non-equivalent control group design). Pemilihan desain sesuai dengan kondisi subjek penelitian, yakni sudah terbentuk secara utuh (naturally format intact group). Subjek penelitian dimaksud yaitu kelompok siswa dalam satu kelas. Populasi penelitian ini yaitu siswa kelas X Program Keahlian Teknik Audio Video (TAV) SMK Negeri 6 Bandung dan sampel yang digunakan yaitu siswa kelas X TAV 3 sebagai kelas eksperimen dengan menggunakan model pembelajaran TGT, dan siswa kelas X TAV 4 sebagai kelas kontrol dengan menggunakan model pembelajaran siklus belajar.

\section{HASIL PENELITIAN}

Data pokok yang diperoleh dalam penelitian ini yaitu data nilai hasil belajar siswa dalam mata pelajaran elektronika digital. Hasil analisis data penelitian diperoleh data sebagai berikut: 
Tabel 1. Perbandingan Nilai Pretes dan Postes

\begin{tabular}{ccc}
\hline Kelas & Pretes & Postes \\
\hline TGT & 53 & 77,9 \\
\hline Learning Cycle & 47 & 68,9 \\
\hline
\end{tabular}

Berdasarkan uji normalitas dan homogenitas yang telah dilakukan sebelumnya didapatkan kesimpulan bahwa data dari kedua sampel yaitu kelas kontrol dan kelas ekperimen berdistribusi normal dan berasal dari populasi dengan varians sama. Tahap berikutnya, yaitu dengan melakukan uji $t$ untuk melihat apakah kedua sampel memiliki rata-rata sama dengan menguji signifikansi perbedaan rata-rata.

Tabel 2. Hasil Uji Hipotesis

\begin{tabular}{|c|c|c|}
\hline Kriteria & Kelas Kontrol & Kelas Eksperimen \\
\hline Jumlah Sampel (n) & 30 & 30 \\
\hline Standar deviasi (S) & 9,34 & 12,37 \\
\hline Varians & 87,15 & 153,09 \\
\hline Rata-rata $(\bar{x})$ & 68,90 & 77,93 \\
\hline $\mathrm{t}_{\text {hitung }}$ & \multicolumn{2}{|c|}{3,19} \\
\hline $\mathrm{t}_{\text {tabel }}$ & \multicolumn{2}{|c|}{1,676} \\
\hline
\end{tabular}

Berdasarkan uji $t$, hasilnya menunjukan bahwa $t$ hitung $>\mathrm{t}$ tabel. Sehingga dapat disimpulkan bahwa terdapat perbedaan penguasaan antara kelas eksperimen dan kelas kontrol setelah diberikan perlakuan atau $\mathrm{H}_{0}$ ditolak.

Tabel 3. Hasil Perhitungan Gain

\begin{tabular}{|c|c|c|}
\hline Kriteria & Kelas Kontrol & Kelas Eksperimen \\
\hline Jumlah Sampel (n) & 30 & 30 \\
\hline Standar deviasi (S) & 0,15 & 0,17 \\
\hline Varians & 0,02 & 0,03 \\
\hline Rata-rata $(\bar{x})$ & 0,58 & 0,73 \\
\hline $\mathrm{t}_{\text {hitung }}$ & \multicolumn{2}{|c|}{3,69} \\
\hline$t_{\text {tabel }}$ & \multicolumn{2}{|c|}{1,676} \\
\hline
\end{tabular}

Berdasarkan pengolahan gain, dapat disimpulkan bahwa peningkatan prestasi belajar siswa pada pokok bahasan gerbang logika kombinasi pada program diklat elektronika digital dengan menggunakan model pembelajaran TGT lebih tinggi dibandingkan dengan peningkatan prestasi belajar siswa dengan menggunakan pembelajaran siklus belajar (learning cycle). 


\section{PEMBAHASAN}

Respon siswa terhadap penggunaan model pembelajaran TGT dan model pembelajaran siklus belajar (learning cycle) sebagian besar sikap siswa menunjukan sikap positif atau setuju pada program diklat Elektronika Digital. Dilihat dari hasil presentase ratarata respon siswa terhadap penerapan pembelajaran model TGT yaitu sekitar $78 \%$ siswa menyatakan setuju. Sedangkan hasil presentase rata-rata respon siswa terhadap penerapan model pembelajaran siklus belajar (learning cycle) yaitu sekitar $72 \%$ siswa menyatakan setuju.

Hasil pengolahan data dan pengujian hipotesis dapat ditemukan bahwa rata-rata nilai mata pelajaran elektronika digital dengan perlakuan TGT lebih tinggi dari pada kelas dengan perlakuan learning cycle. Terdapat perbedaan penguasaan antara kelas eksperimen dan kelas kontrol setelah diberi perlakuan. Peningkatan prestasi belajar siswa pada pokok bahasan rangkaian kombinasi pada mata pelajaran elektronika digital dengan menggunakan model pembelajaran TGT lebih tinggi dibandingkan dengan peningkatan prestasi belajar siswa dengan menggunakan pembelajaran siklus belajar. Respon siswa terhadap penerapan model TGT lebih besar dibandingkan model learning cycle.

Berdasarkan hasil pengolahan data, diperoleh rata-rata nilai mata pelajaran elektronika digital dengan perlakuan TGT sebesar 77,93 dan pada kelas perlakuan learning cycle sebesar 68,90. Bila kita mengacu kepada skala seratus yaitu dengan criteria 90-100 (amat baik); 75-89 (baik); 60-74 (cukup); dan 60-59 (kurang). Hal tersebut dapat diinterpretasikan bahwa nila rata-rata mata pelajaran elektronika digital dengan perlakuan TGT termasuk pada kategori baik. Pada kelas dengan perlakuan learning cycle termasuk pada kategori cukup. Hal ini mungkin disebabkan oleh respon siswa yang menunjukkan sikap positif terhadap model pembelajaran TGT sebesar $78 \%$ dibandingkan model pembelajaran learning cycle $72 \%$. Selain itu pada pembelajaran TGT adanya heterogenitas anggota kelompok, dengan harapan dapat memotivasi siswa untuk saling membantu antar siswa berkemampuan lebih dengan siswa yang berkemampuan kurang dalam menguasai materi pelajaran. Hal ini akan menyebabkan tumbuhnya rasa kesadaran pada diri siswa bahwa belajar secara kooperatif itu menyenangkan. Selanjutnya untuk memastikan bahea seluruh anggota kelompok telah menguasai seluruh pelajaran, maka seluruh siswa akan diberi permainan akademik.

Selanjutnya berdasarkan uji t dimana hasilnya menunjukkan bahwa t hitung $=3,19$ dan $\mathrm{t}$ tabel $=1,676$, maka dapat disimpulkan bahwa terdapat perbedaan penguasaan antara kelas eksperimen dan kelas kontrol setelah diberikan perlakuan. Hal ini mungkin disebabkan oleh beberapa hal dimana pada kelas eksperimen siswa mengerjakan LKS atau modul dan mempresentasikannya. Adanya turnamen akademik yang bersifat permainan dengan membagi 
kelompok secara heterogen. Penghargaan kelompok dan pergeseran setelah pelaksanaan turnamen akademik, sedangkan pada model learning cycle (kelas kontrol) tidak ada turnamen akademik. Pada saat fase pengenalan konsep pengetahuan awal siswa lebih digali, pembelajaran lebih bersifat diskusi dengan siswa sekelasnya ataupun dengan guru.

Berdasarkan uji t data gain ditemukan bahwa peningkatan prestasi belajar siswa pada pokok bahasan rangkaian kombinasi pada mata pelajaran elektronika digital dengan menggunakan model pembelajaran TGT lebih tinggi dibandingkan dengan peningkatan prestasi belajar siswa dengan menggunakan model pembelajaran lerning cycle. Hal ini disebabkan oleh beberapa hal seperti sudah dijelaskan pada temuan sebelumnya yaitu nilai rata-rata mata pelajaran elektronika digital pada pokok bahasan rangkaian kombinasi lebih tinggi pada kelas eksperimen dibandingkan kelas kontrol. Penguasaan materi pelajaran kelas eksperimen lebih tinggi dari pada penguasaan materi kelas kontrol, peningkatan prestasi belajar siswa pada pokok bahasan rangkaian kombinasi pada mata pelajaran elektronika digital dengan model pembelajaran TGT lebih tinggi dibandingkan dengan peningkatan prestasi belajar siswa dengan menggunakan pembelajaran learning cycle. Respon siswa terhadap model pembelajaran TGT lebih besar dari pada model pembelajaran learning cycle.

Hasil penelitian memberikan gambaran bahwa model pembelajaran kooperatif tipe TGT dapat meningkatkan prestasi belajar siswa. Agar peningkatan prestasi belajar lebih baik dari penelitian yang penulis lakukan, dibutuhkan dukungan fasilitas, kreatifitas, alat dan biaya cukup memadai. Hendaknya peneliti mempersiapkan pembelajaran secara matang. Disamping itu memerlukan lebih banyak tenaga, pemikiran, dan waktu.

Peranan guru dalam proses belajar mengajar dengan model pembelajaran kooperatif tipe TGTcenderung dominan. Agar kegiatan pembelajaran tetap terkontrol dan berjalan dengan kondusif. Slain itu, guru harus lebih mempersiapkan diri dalam memberikan pengajaran agar siswa dapat lebih aktif dalam kegiatan belajar mengajar, sehingga seluruh potensi siswa dapat teroptimalkan.

Aktivitas siswa selama pembelajaran menunjukan bahwa, penerapan model pembelajaran kooperatif tipe TGT dapat meningkatkan aktivitas belajar siswa seperti mendengarkan atau memperhatikan guru pada saat penyajian materi. Mencatat hal-hal penting tentang informasi yang didapat pada proses pembelajaran, membaca, dan mengerjakan tugas. Saling kooperatif selama PBM dan menjaga kekompakan dalam belajar serta dalam diskusi sehingga dapat memecahkan masalah dan mempresentasikan kerja kelompok. Aktivitas siswa adalah keterlibatan siswa dalam bentuk sikap, pikiran, perhatian dalam kegiatan belajar guna menunjang keberhasilan proses belajar mengajar dan memperoleh manfaat dari kegiatan tersebut. 
Dalam kegiatan pembelajaran ini telah nampak kegiatan pembelajaran yang menempatkan siswa sebagai pusat kegiatan belajar mengajar (student centered). Sedangkan guru hanya bertindak sebagai fasilitator dan pendorong siswa belajar lebih giat, sesuai dengan indikator aktivitas siswa. Hasil penelitian menunjukkan, pertama mayoritas siswa beraktivitas dalam pembelajaran. Kedua, aktivitas pembelajaran didominasi oleh siswa. Ketiha mayoritas siswa mampu mengerjakan tugas yang diberikan guru melalui pembelajaran kooperatif.

Kesan dan tanggapan guru melalui wawancara menyatakan bahwa dengan menerapkan model TGT kondisi kelas menjadi lebih aktif. Siswa menjadi berani tampil dalam mengungkapkan pendapatnya. Sedangkan kesan dan tanggapan siswa menyatakan bahwa kegiatan belajar jadi lebih menyenangkan dan dapat terlatih memecahkan contoh permasalahan melalui kegiatan praktikum. Kendala yang dihadapi dalam menerapkan model TGT dalam kegiatan pembelajaran eletronika digital. Diantaranya yaitu pada saat pembelajaran melalui tahapan TGT guru merasa kesulitan dalam mengorganisasikan waktu. Dalam melaksanakan tahapan kegiatan praktikum masih dihadapi dengan kendala keterbatasan alat-alat praktikum. Kemudian pada tahapan presentasi hasil praktikum, siswa masih kurang terbiasa tampil menyampaikan pendapatnya di depan kelas.

Peningkatan kemampuan akedemik yang dimiliki oleh peserta didik dalam pembelajaran kooperatif tipe TGT, tentu tidak terlepas dari keterlibatan peserta didik yang lain dalam kelompok dimana mereka berkumpul. Oleh karena, berdasarkan pengertian tentang pembelajaran kooperatif. Para peserta didik berkumpul dalam sebuah kelompok dengan jumlah anggota antara 4-5 oranng dengan karakteristik (tingkat kemampuan, jenis kelamin, suku, ras, dan lain-lain) yang heterogen. Hal ini yang perlu difahami bahwa dalam pembelajaran kooperatif, terdapat hal-hal positif seperti hubungan saling menguntungkan, semangat kerja kelompok. Semangat kompetisi dan komunikasi yang efektif antara anggota kelompok. Dengan hal-hal tersebut, sudah barang tentu para peserta didik akan belajar dengan senang, karena tidak dilakukan dibawah tekanan. Hal ini sesuai dengan beberapa ciri dari pembelajaran kooperatif, yaitu: (a) setiap anggota memiliki peran, (b) terjadi hubungan interaksi langsung di antara peserta didik, (c) setiap anggota kelompok bertanggung jawab atas belajarnya dan juga teman sekelompoknya, (d) guru membantu mengembangkan keterampilan interpersonal kelompok, (e) guru hanya berinteraksi dengan kelompok saat diperlukan. Selain itu, dalam pembelajaran koopertaif, terdapat tiga konsep sentral yang menjadi karakteristik pembelajaran kooperatif yaitu penghargaan kelompok, pertanggungjawaban individu, dan kesempatan yang sama untuk berhasil.

Kenyataan ini menunjukkan bahwa pembelajaran kooperatif dapat meningkatkan pemahaman peserta diklat terhadap materi pelajaran yang diikutinya. Kenyataan ini sesuai 
dengan tujuan yang ingin dicapai dalam pembelajaran kooperatif, khususnya dimilikinya kemampuan akademik oleh peserta didik. Hal ini sejalan dengan tujuan pembelajaran kooperatif, yaitu agar peserta didik memiliki kemampuan baik dalam aspek akademik, pengakuan terhadap perbedaan individu, dan keterampilan sosial.

\section{KESIMPULAN}

Kesimpulan penelitian ini yaitu terdapat perbedaan yang signifikan antara hasil belajar peserta didik dengan menggunakan model pembelajaran kooperatif tipe TGT dan dengan menggunakan model siklus belajar learning cycle. Peningkatan prestasi belajar siswa pada pokok bahasan gerbang logika kombinasi pada program diklat elektronika digital dengan menggunakan model pembelajaran TGT lebih baik dibandingkan dengan peningkatan prestasi belajar siswa dengan menggunakan pembelajaran learning cycle. Oleh karena itu, untuk pembelajaran pada pelajaran ini disarankan untuk menggunakan model pembelajaran TGT. Namun demikian, model pembelajaran learning cycle tidak baik, tetapi kurang cocok untuk diterapkan pada mata pelajaran ini. Kedua model pembelajaran tersebut memiliki karakteristik yang berbeda, sehingga dalam penerapan juga berbeda. Oleh karena penerapannya berbeda, maka hasil yang diperolehnya juga berbeda. Sesungguhnya tidak ada model pembelajaran yang paling, namun aka nada model pembelajaran yang paling cocok atau tepat untuk diterapkan. Baik diterapkan secara sendiri atau diterapkan secara kombinasi dengan model lain.

\section{DAFTAR PUSTAKA}

Asmani, J.M. (2009). Sekolah Life Skills Lulus Siap Kerja. Yogyakarta: Diva Press.

Budiningsih, C. Asri. (2005). Belajar dan Pembelajaran. Jakarta: Rineka Cipta.

Depari, Ganti. (2011). Teknik Digital. Bandung: Nuansa Aulia.

Isjoni. (2009). Cooperative Learning Efektifitas Pembelajaran Kelompok. Bandung: Alfa Beta.

Lie, Anita. (2002). Cooperative Learning Mempraktikkan Cooperative Learning di Ruangruang Kelas. Jakarta: PT Grasindo.

Lie, Anita. (2007). Cooperative Learning. Jakarta: Grasindo

Sardiman. A.M. (2011). Interaksi dan Motivasi Belajar Mengajar. Jakarta: PT. RajaGrafindo Persada.

Slavin, E. Robert. (2008). Cooperative Learning Teori, Riset dan Praktik. Bandung: Nusa Media. 
Solihatin, E. dan Raharjo. (2007). Cooperative Learning Analisis Model Pembelajaran IPS. Jakarta: Bumi Aksara.

Sondang, P. Siagian. (2003). Manajemen Sumber Daya Manusia. Jakarta: Bumi Aksara.

Sudibyo, Elok. (2002). Beberapa Model Pengajaran dan Strategi Belajar dalam Pembelajaran Fisika. Jakarta: Departemen Pendidikan Nasional.

Suparno, Paul. (1997). Filsafat Konstuktivisme dalam Pendidikan. Yogyakarta: Kanisius.

Trianto. (2007). Model-Model Pembelajaran Inovatif Berorientasi Kontruktivistik. Jakarta: Prestasi Pustaka.

Widjanarka, Wijaya. (2006). Teknik Digital. Jakarta: Erlangga. 